\title{
Determinants of Arrears in the Municipal Savings Banks, Rural Savings Banks and EDPYMES of Peru
}

\author{
Margarita Elluz Calle Arancibia ${ }^{1}$, Wagner Enoc Vicente Ramos ${ }^{1} \&$ Gustavo Ilich Loayza Acosta ${ }^{1}$ \\ ${ }^{1}$ School of Economics, Universidad Continental, Peru \\ Correspondence: Margarita Elluz Calle Arancibia, Teacher and researcher of School of Economics, Universidad \\ Continental, Peru.
}

Received: February 26, 2020

Accepted: May 17, 2020

Online Published: July 15, 2020

doi:10.5430/ijfr.v11n4p523

URL: https://doi.org/10.5430/ijfr.v11n4p523

\begin{abstract}
The objective this paper is analyzed the relationship between the administration of the working capital and the profitability of assets of the companies of the Peruvian agricultural sector of the period 2009-2018. Through an econometric model it was obtained that the ROA is significantly related to the PPI ( $p<0.05)$, PPC $(p<0.05)$ and PPP $(\mathrm{p}<0.10)$. This indicates that the profitability of these companies depends on the application of appropriate policies regarding their inventories, accounts receivable and accounts payable.
\end{abstract}

Keywords: working capital management, return on assets, sugar agricultural enterprises, Peru

\section{Introduction}

Microfinance emerges as an important tool to improve the lives of millions of people, by providing loans to micro and small businesses, which are involved in most of the country's economic activities. Accordingly, microfinance provides accessibility and closeness, contributing to the construction of inclusive and alternative financial systems, with important effects for the development of the country (Gutierrez, 2008).

The development of microfinance in Peru in recent years has been vertiginous. So much so, that according to the Global Microscope 2016 prepared by The Economist Intelligence Unit magazine, Peru achieved first place for tenth consecutive year, mainly due to the regulatory environment and the good conditions for the development of microfinance.

As a result, currently Peru is has recognized as one of the most mature microfinance markets not only in Latin America but also worldwide thanks to the performance shown. Thus, the Mypes, a segment to which microfinance institutions (from now on, MFIs) are directed, generate almost $24 \%$ of GDP, and approximately $60 \%$ of the economically active population employed in the country, thus contributing to a greater generation of employment (Ministerio de Producción, 2018).

Microfinance in Peru mainly comprises three types of institutions: The Municipal Savings and Credit Funds (CM), the Rural Savings and Credit Funds (CR) and the Small and Micro Enterprise Development Entities (EDP). These institutions date back to the end of the 90s where they granted loans to almost 300 thousand clients, $19.2 \%$ of the total financial system, although their participation in the total amount of loans was reduced (1.3\%). It is necessary to specify that more than $60 \%$ of these placements have gone towards to microenterprises, which represent an important part of microfinance (Murrugarra \& Ebentreich, 1999). Additionally, as mentioned (Ergungor \& Thomson, 2006), banking crises, both those of a systemic nature and those affecting individual entities, tend to have solvency problems derived from the deterioration of the assets of the assets as one of their main causes entities, specifically, the arrears of their loan portfolios. In addition to this, arrears problems can lead to problems of profitability, liquidity and finally a solvency problem (Guillén, 2001). In that sense, knowing the determinants drives to look for tools to be alert to crisis events in the financial system and implement the necessary actions.

In the investigation, it was proposed to establish the factors that determine the arrears of micro business institutions in Peru, and what are the repercussions in the development of these institutions to promote a more solid and sustainable system in the short and long term, which It will improve the financing of the Mype sector. 


\section{Literary Review}

\section{Relevant historical aspects}

The history of microfinance is born since the mid-1800s, when theorist Lvsander Spooner wrote about the benefits of small loans to entrepreneurs and farmers as a way to get people out of poverty. However, it must take into account that each developed and developing country has its own history of microfinance development (Seibel, 2003).

Yale's economic historian, Timothy Guinnane, conducted research on the movement of the Friedrich Wilhelm Raiffeise town bank in Germany, which began in 1864 and by 1901; the bank reached two million rural farmers. Timothy Guinnane, thus demonstrated that microcredits could pass two tests concerning payment morale and the possibility of providing financial services to poor people (Lender, 2019).

In developing economies and particularly in rural areas, many activities that are classifieds in the developed world as financial ar not monetized, that is, money is not using to carry them out. Later people find creative and often collaborative ways to meet these needs, mainly through the creation and exchange of different forms of non-monetary value. Common cash substitutes vary from country to country, but usually include cattle, grains, jewelry and precious metals. Robinson (2001) mentions that in the 1980s it was demonstrated that "microfinance could provide large-scale benefits", and in the 1990s, "microfinance began to develop as an industry" (2001, p. 54).

Today, the use of the term "microfinance" has its roots in the 1970s, when organizations such as the Grameen Bank of Bangladesh with microfinance pioneer Mohammad Yunus started and shaped the modern microfinance industry. Another pioneer in this sector is Akhtar Hammed Khan. In those days, a new wave of microfinance initiatives introduced several innovations in the sector. Many companies began experimenting with loans to people who could not access the existing financial system because they were careless. In the 2000s, the goal of the microfinance industry is to meet unsatisfied demand on a much larger scale and play a role in poverty reduction. Then Hermes (2014) states that microfinance is the right tool to reduce income inequality, allowing citizens of lower socioeconomic classes to participate in the economy.

Financial crises, and particularly banking crises, have intensified in the past decade. These episodes have not only been seen exclusively in developing economies; such as Chile, Argentina, Paraguay, Ecuador and Venezuela; on the contrary, they have also occurred in industrialized countries such as Japan and the United States. These crises have generated large drops in production and high fiscal losses (Caprio, 1998). Likewise, it was observed that in studies such as that of Caprio and Klingebiel (1996) it is analyzed that the accumulated reductions of the Gross Domestic Product (GDP) vary from $10 \%$ to 55\%; while fiscal costs, between $6 \%$ and $40 \%$ of GDP.

Otherwise, Bernanke and Gertler (1989) and Kiyotaki and Moore (1997) explain that the financial system can serve as an amplifying mechanism for economic cycles, so that the management of economic policy is very sensitive to the financial system, a reflection of this, there are the cases of the United States, Japan and the United Kingdom in the 1990s, which due to banking problems was enough to restrict recovery efforts. Then, the timely detection of the financial fragility of the financial entities, allows the necessary corrective measures to be implemented to restore soundness and limit potential losses (Morón \& Rudy, 2003).

Added to this are the various factors that influence arrears, Hardy and Pazarbasioglu (1999) identify that macroeconomic and financial variables can serve as early warning indicators. The authors, using a multinomial model, find more significant findings that reveal that the problems faced by banks are related to contemporary falls in GDP, periods of higher inflation, expansion of aggregate credit, higher capital flows, increase in real interest rates, fall in the real exchange rate and adverse shocks in the terms of trade.

For his part, Díaz (2010) in an analysis of the determinants of the level of default in the Bolivian financial system during the period 2001-2008, including macro and microeconomic factors, in which they indicate that the liquidity restrictions measured from the Active interest rates, the devaluation of the national currency and the higher indebtedness of companies have effects on delinquencies.

Today, the World Bank estimates that more than 16 million people have the offer of 7,000 financial institutions worldwide. The experts of the CGAP (Consultative Group to Assist the Poor) report that around 500 million families benefit from these small loans, making new business possible. At the microcredit summit in Washington D.C. The goal was to reach 100 million of the poorest people through loans from world leaders and larger financial institutions (Lender, 2019).

In another study similar McCann and McIndoe-Calder (2012) studied the determinants of the probability of default of small and medium-sized companies in Ireland, in which they found that the main financial indicators that are 
predictors Significant probabilities of bankruptcy in banking institutions focus on debt to total assets ratio, solvency ratio, the leverage ratio and the profitability indicator.

In the 1970s and 1980s, the Peruvian economy went through a series of deep and prolonged economic crises that generated huge losses in its Gross Domestic Product (GDP). The GDP per capita registered an average rate of 0\% during those years, an unfortunate result even when compared to the growth rate that Latin America had (Gonzalo \& Panizza, 2015). The development of microfinance institutions in Peru, and their credit technologies began during the 80 s, in a national economic context characterized by corruption, galloping inflation, debt crisis, weather disasters and low dynamism of economic activity. This situation was evidence in the disappearance of financial institutions oriented to startups and emerging sectors, such as savings banks, cooperatives and mutuals; those that survived depended on subsidies and were unsustainable in the long term (Quispe, León, \& Contreras, 2012). In 1980, legislative decree 23039 was promulgated, which allowed the creation of municipal savings and credit funds, being able to establish the scope of action outside the metropolitan territory of Lima and Callao, as this was the main objective of the creation of the CMAC, the decentralization. In the 1990s, a beneficial environment for the development of microfinance institutions in Peru was presente. The Rural Savings and Credit Institutions (CRAC) were create, oriented to the agricultural sector at first, then and due to the existing demand, the commercial credit lines to medium and small businesses were extended in their portfolio of products.

Quispe, León and Contreras (2012), highlight that in the 2000s the increase in the number of financial institutions that granted loans to microenterprises was observe, thereby increasing competition in the sector, and therefore the rate of average interest from 55\% in 2002 to $32 \%$ in 2009. Thus, a significant increase in the number of formal microcredits was achieved from 300 thousand in 2002 to 2.1 million in 2010; as well as the volume of this credit, from S / 1.5 billion to S / 20.2 billion (4.8\% of GDP) in the same period, which implies a growth of more than 10 times in real terms. For 2016, microfinance institutions strengthened the collection and risk area due to the over-indebtedness of the financial system; in addition, some microfinance institutions increased their equity levels through alliances and mergers such as CRAC Chavín and Edpyme Raíz in May 2016 and for July of the same year, the financial Credinka merges with CRAC Cajamarca. On the other hand, the recovery in the movement of loans that has not occurred since 2014 is emphasized, since in 2016 a growth rate of $13.12 \%$ is shown, which is higher than in September (5.3\%) and December (6.7\%) of 2015 (Global Microfinance, 2019).

The increase in offices was also notable during 2016, being the southern, northern and Lima regions where there were more agency openings. In this way, the microfinance sector has reached an unexpected growth, which generates a good investment climate, attracting specialized foreign funds in this credit segment.

\section{Current situation of microfinance in Peru}

According to the "Analysis of the Peruvian Microfinance System", carried out by Equilibrium (2018) at September 30, 2018, the Peruvian microfinance system was constitute of 176 entities. Of which 38 are entities supervised by the SBS (21.6\%), 128 correspond to Savings and Credit Cooperatives regulated (Note 1) by the SBS, but supervised (Note 2) by the National Federation of Savings and Credit Cooperatives - Fenacrep (72.7\%) and 10 are unregulated entities (5.7\%). It should was note that the latter group considers those enrolled in the self-regulation program promoted by the Consortium of Private Organizations for the Promotion of Small and Microenterprise Development - Copeme.

Regarding the entities supervised by SBS, so far in 2018 there are no changes in the participants, are compose of eleven CMAC, eleven financial, nine Edpymes, six CRAC and a bank specialized in microfinance. In relation to the Savings and Credit Cooperatives, there is a significant change in the number of entities so far this year, from 151 in December 2017 to 128 in September 2018.

Although the Savings and Credit Cooperatives not authorized to attract resources from the public (Coopac) (Note 3) have a greater participation in the number of entities per credit portfolio, it is the microfinance entities regulated and supervised by the SBS that are most relevant with a participation above $80.0 \%$ (Note 4 ) of the total microfinance system.

It should be taken into account that, in 2017, the Phenomenon of the Child happened, which brought with it a negative effect on local economic activity, and therefore on the performance of microfinance entities. The SBS adopted exceptional (Note 5) measures with the objective of preserving the operation of the financial system, thus, it allowed companies in the sector to reprogram ex officio and unilaterally retail loans; In addition to individual reprogramming, aimed at debtors affected by temporary events or situations that affect their cash flows.

Despite registering a decrease in the microfinance portfolio quality, for 2018 there were improvements in terms of 
efficiency that allowed a favorable evolution of the main profitability indicators. In addition, it is observe that some entities have increased their participation in loans to medium-sized companies, in particular some CRAC and Edpyme, which constitutes a greater risk by involving loans of greater amounts.

\section{Arrears in Payment of microfinance institutions}

The regulators of the financial system of the different countries use different methodologies for the calculation of arrears, according to the characteristics of each country. Countries consider different days of arrears to classify a loan as an overdue portfolio. Some of them, such as Chile and Brazil, use a 90-day threshold, while others, Colombia and Mexico, consider only 30 days. In Peru, a more conservative arrears criterion is follow than in the aforementioned countries. Thus, a credit is considere past due when it has more than 15 days of delay for corporate loans, large, medium-sized companies, and more than 30 days for loans to small and micro enterprises. In the case of mortgage and consumer loans, the installment with more than 30 days past due and the balance after 90 days past due is considered past due. Likewise, in Peru, the refinanced portfolio, which considers loans that have registered variations in the term or amount of the original contract due to difficulties in the debtor's ability to pay, is also usually included in arrears indicators. The latter is not part of the arrears indicators that other countries report to the "International Financial Statistics" compendium of the International Monetary Fund (IMF).

The analysis of the quality of a financial institution's portfolio requires the use of an appropriate indicator for such purposes. There is, however, no unanimity in the discussion about what this "adequate indicator" of the arrears levels exhibited by a credit institution's portfolio. From the financial information published by the Superintendence of Banking and Insurance, the report of two portfolio quality indicators that quantify in relative values the level of arrears portfolio or higher credit risk is evidence. The indicators are backlog and high-risk portfolio (Aguilar \& Camargo, 2003).

This ratio was select as it reflects the credit risk of the bank: those banks with a high proportion of problematic assets must cover the losses associated with those assets by reducing their profits and, finally, their capital. Therefore, a high portfolio rate behind gross loans is positively related to the probability of insolvency or financial bankruptcy (Muñoz, 1999). It should be note that the arrears indicator is found as public information on the SBS website.

When considering this rate, it is necessary to take into account the statistical effect that may occur, given the construction of the arre rate. Thus, given that the ratio is composed of the backlog over the total portfolio, it will rise each time the numerator (the backlog) shows a relative growth greater than the denominator (the total portfolio) (ASBANC, 2016).

Therefore, the arrears maintain an important because it is a direct indicator about the customer payment capacity, additionally; his has an impact on the liquidity of the company in the short term. In addition, exists the possibility of affecting the level solvency in the long term and imply the imminent bankruptcy of the financial institution if the inconveniences are not resolved in time.

\section{Methodology}

\subsection{Population and Sample}

This is a non-experimental, retrospective, correlational study, whose population under analysis corresponds to 22 micro-financial entities in a period of 81 months: between January 2011 and September 2017. The data and information required were obtained. as secondary information in institutions such as the Superintendence of Banking and Insurance and AFP (SBS) and Central Reserve Bank of Peru (BCRP). For the selection of the sample, the criterion of a strongly balanced panel (Levin, Lin, \& Chu, 2002) and (Tzavallis \& Harris, 1999) was take into account; therefore the present investigation did not consider the Savings and Credit Cooperatives, since they do not present data available for the established time series.

Having previously cleared the entities with deviations on the date of entry / exit with respect to the analysis, the balanced panel is correctly configured comprising the following characteristics: 18 microfinance entities, 81 months of temporary analysis (January 2011 - September 2017), with a total of 1458 resulting observations shown in Table 1. 
Table 1. Microfinance entities included in the study

\begin{tabular}{lll}
\hline $\mathbf{N}^{\circ}$ & $\begin{array}{l}\text { Microfinance entities included in } \\
\text { the population }\end{array}$ & $\begin{array}{l}\text { Microfinance entities in the } \\
\text { balanced panel }\end{array}$ \\
\hline 1 & CMAC Sullana & CMAC Sullana \\
2 & CMCP Lima & CMCP Lima \\
3 & CMAC Piura & CMAC Piura \\
4 & CMAC Arequipa & CMAC Arequipa \\
5 & CMAC Cusco & CMAC Cusco \\
6 & CMAC Huancayo & CMAC Huancayo \\
7 & CMAC Ica & CMAC Ica \\
8 & CMAC Maynas & CMAC Maynas \\
9 & CMAC Paita & CMAC Paita \\
10 & CMAC Del Santa & CMAC Del Santa \\
11 & CMAC Trujillo & CMAC Trujillo \\
12 & CMAC Tacna & CMAC Tacna \\
13 & CRAC Señor de Sipán & CRAC Señor de Sipán \\
14 & CRAC Los Andes & CRAC Los Andes \\
15 & CRAC Prymera & CRAC Prymera \\
16 & Edpyme Credivisión & Edpyme Credivisión \\
17 & Edpyme Acceso Crediticio & Edpyme Acceso Crediticio \\
18 & Edpyme Alternativa & Edpyme Alternativa \\
19 & CRAC Incasur & \\
20 & CRAC del Centro & \\
21 & CRAC Raíz & \\
22 & CRAC Chavín & \\
\hline & & \\
\hline
\end{tabular}

\subsection{Data Collection Instrument}

\subsubsection{Study Variables}

The use of the variables is summarizing a continuation (Table 2):

Table 2. Operationalization of the variables

\begin{tabular}{lll}
\hline Variable & Conceptual definition & Operational definition \\
\hline Delinquincy ratio & $\begin{array}{l}\text { Proportion in default of the total loan portfolio } \\
\text { of the bank and / or micro financial entity. }\end{array}$ & $\frac{\text { Cartera Morosa }}{\text { Cartera Total }}$ \\
$\begin{array}{ll}\text { Credit Growth Ratio } \\
(\mathrm{MN})\end{array}$ & $\begin{array}{l}\text { Variation in the total amount of credits, } \\
\text { monthly. }\end{array}$ & $\frac{\text { Monto créditos }_{\mathrm{t}}-\text { Monto créditos }_{\mathrm{t}-1}}{\text { Monto créditos }_{\mathrm{t}-1}}$ \\
GDP variation & $\begin{array}{l}\text { Percentage change of GDP with respect to its } \\
\text { status in the previous period. }\end{array}$ & $\frac{\mathrm{PBI}_{\mathrm{t}}-\mathrm{PBI}_{\mathrm{t}-1}}{\mathrm{PBI}_{\mathrm{t}-1}}$ \\
Active interest ratio & $\begin{array}{l}\text { Interest ratio (TREA) charged by microfinance } \\
\text { (to small companies) }\end{array}$ & $\begin{array}{l}\text { institutions, to small businesses in Peru } \\
\text { Definida por instituciones } \\
\text { microfinancieras }\end{array}$ \\
(MN) & (SMEs), in national currency. &
\end{tabular}


Percentage of the population that is outside the

Unemployment ratio

PEA, with respect to the total population $\frac{\text { PEA }}{\text { PET }}$ qualified to work.

CPI variation

Percentage variation of the Consumer Price Index (Metropolitan Lima base).

$\frac{\mathbb{P P C}_{\mathrm{t}}-\mathbb{I P C}_{\mathrm{t}-1}}{\mathbb{P P C I}_{\mathrm{t}-1}}$

Proportion of total assets, which represents the Liquidity

$(\mathrm{MN})$ current availability of cash by the microfinance institution.

$\frac{\text { Activos en caja }}{\text { Total de activos }}$

Net Profit (MN) Monthly utility of financial institutions.

Net financial margin - administrative expenses

Caja Municipal/ Metropolitana

Indicates membership in the type of
microfinance institution: Municipal /
Metropolitan Fund.

$0=$ Otro tipo de inst. Microfinanciera

Caja Rural

Indicates belonging to the type of microfinance

$1=$ Caja Rural institution: Caja Rural.

$0=$ Otro tipo de inst. Microfinanciera

Indicates belonging to the type of microfinance $1=$ EDPYME

EDPYME institution: EDPYME

$0=$ Otro tipo de inst. Mierofinanciera

\subsubsection{Econometric Model}

The data were process with Microsoft Excel and Stata version 15 to treat the characteristics of the variables (heterocedasticity, unit root test, heterogeneity not observed, significance of the variables, non-autocorrelation test). With them, we were work to be able to order it and formulate an econometric model, from which useful conclusions were, obtain to achieve the objective of the investigation.

Below is shows the econometric model used that replicates the complex reality of analyzing the arrears rate of microfinance institutions, through the dual analysis of partial correlation, and heterogeneity not observed.

$$
\begin{aligned}
& \text { Morosid }_{\mathrm{i}, t}=\gamma+\rho * \text { Morosid }_{\mathrm{i}, t-1}+\beta_{1} * T_{\mathrm{i}, \mathrm{t}}+\beta_{2} * \operatorname{TDES}_{\mathrm{t}}+\beta_{3} * \operatorname{VarIPC}_{\mathrm{t}}+\beta_{4} * \operatorname{VarPBI}_{\mathrm{t}}+\beta_{5} * R L q_{\mathrm{i}, t} \\
& +\beta_{6} * T C C_{i, t}+\beta_{7} * U N_{i . t}+\beta_{9} * C M A C_{i}+\beta_{9} * C R A C_{i}+\beta_{10} * E D P Y M E_{i}+v_{i, t}
\end{aligned}
$$

Considering that:

$$
v_{i, t}=u_{i, t}+\theta_{i}+\delta_{t}, \rho<1 Y_{i, t}, X_{i, t} \text { estacionarias }
$$

Where:

Morosid: Arrears ratio

IT: Active interest ratio (SME)

TDES: Unemployment Ratio

VarIPC: IPC Variation 
VarPBI: GDP variation

RLq: Liquidity ratio

CBT: Loan Growth ratio

UN: Net Profits

CMAC: Municipal / Metropolitan Caja Membership

CRAC: Rural Caja Membership

EDPYME: Edpyme membership

In addition, the Arellano Bond variant was apply:

$$
\begin{aligned}
& \text { MMorosid }_{\mathrm{i}, \mathrm{t}}=\rho * \text { Morosid }_{\mathrm{i}, \mathrm{t}-1}+\beta_{1} * \text { TI }_{\mathrm{i}, \mathrm{t}}+\beta_{2} * \operatorname{TDES}_{\mathrm{t}}+\beta_{3} * \operatorname{VarIPC}_{\mathrm{t}}+\beta_{4} * \operatorname{VarPBI}_{\mathrm{t}}+\beta_{5} * R L q_{\mathrm{i}, \mathrm{t}} \\
& +\beta_{6} * T C C_{i . t}+\beta_{7} * U N_{i . t}+\beta_{8} * C M A C_{i}+\beta_{9} * C R A C_{i}+\beta_{10} * E D P Y M E_{i}+\Delta v_{i t}
\end{aligned}
$$

Considering that: $\Delta$ Morosid $_{i, t-1}=\rho *(\rho-1)$ Morosid $_{i, t-3}+(\rho-1) v_{i t-2}+v_{i t-1}$

Where:

Morosid: Arrears ratio

IT: Active interest rate (SME)

TDES: Unemployment ratio

VarIPC: IPC Variation

VarPBI: GDP variation

RLq: Liquidity ratio

CBT: Loan Growth ratio

UN: Net Profits

CMAC: Municipal / Metropolitan Caja Membership

CRAC: Rural Caja membership

EDPYME: Edpyme membership

\subsection{Analysis of Data}

a) Stationarity of the Panels

The results in table 3 check the seasonality of the panel. In addition, thanks to the asymptotics of the HT and IPS tests, you can infer that both the dynamic panel methodology (requires several observations to comply with what IPS proposes) and that of Arellano Bond (it has a limited number of temporary observations, which satisfies what was proposed by HT) were relevant for this investigation.

\begin{tabular}{|c|c|c|c|}
\hline \multirow{2}{*}{$\frac{\text { Variable Morosid }}{\text { Test }}$} & \multicolumn{3}{|c|}{ Stationarity of the panels } \\
\hline & Levin-Lin-Chu (LLC) & Harris-Tzavalis (HT) & Im-Pesaran-Shin (IPS) \\
\hline Asintóticas & $\mathrm{N} / \mathrm{T}->0$ & $\mathrm{~N} \rightarrow \infty$, T Fijo & $\mathrm{T}, \mathrm{N}->\infty$ \\
\hline$H_{0}$ & Paneles Raíz Unitaria & Paneles Raíz Unitaria & Paneles Raíz Unitaria \\
\hline \multirow{2}{*}{$H_{1}$} & \multirow{2}{*}{ Paneles Estacionarios } & \multirow{2}{*}{ Paneles Estacionarios } & Algunos paneles \\
\hline & & & Estacionarios \\
\hline P. Value & 0.0049 & 0.0001 & 0.0000 \\
\hline
\end{tabular}

Table 3. Stationarity of the panels 
b) Heterocedasticity present

The Simple Heteroskedasticity test seeks to verify that: $\sigma_{i}^{2}=\sigma^{2} \quad \forall i \in \mathbb{N}$

Where: $\sigma_{i}^{2}=\operatorname{Var}\left(u_{i}\right)$ that is, constant variance.

In Table 4, it was possible to verify that there is Heterocedasticity in the model, so it is pertinent to correct the errors through robust methodologies. The Clustering methodology by ID was applied to correct the heterocedasticity.

Table 4. Test de Estacionariedad

\begin{tabular}{ll}
\hline Test & Heterocedasticidad \\
\hline Valor Chi2 & 9498.39 \\
P. value & 0.0000 \\
\hline
\end{tabular}

c) Heterogeneity not observed

In order to verify the heterogeneity not observed, the Breusch-Pagan Test was performed, which compares the estimation of random effects vs. the pooled estimate (or MCO panel).

Under a random effects model: Morosid $_{i_{2} t}=\gamma+\beta * X+u_{i}+v_{i_{i} t}$

In table 5, it is observe that the test is rejects,

$$
H_{0}: \operatorname{Var}\left(u_{i}\right)=0
$$

Therefore, it is pertinent to model taking into account the heterogeneity not observed.

Table 5. Test de Breusch-Pagan de Heterogeneidad

\begin{tabular}{cc}
\hline Test & Breusch-Pagan \\
\hline$H_{0}$ & $\operatorname{Var}\left(u_{i}\right)=0$ \\
P. value & 0.0000 \\
\hline
\end{tabular}

d) Individual significance of the explanatory variables of the model

Table 6 shows the significant variables for both models such as Arrears, which is significant at $1 \%$ and has a high positive coefficient; net profit, which is significant at $5 \%$ in the random effects model and $1 \%$ in the fixed effects model; however, its estimated coefficient is too low to have a proportionate impact on arrears. The loan growth rate (significant at $5 \%$ in random effects and $10 \%$ in fixed effects) that positively affects the arrears ratio by $4.5 \%$ for each additional unit in the rate. The variation of the GDP is significant at $1 \%$ in both scenarios and with an effect of -0.02, which implies a positive reaction to the economic boom, reducing the arrears ratio. The last significant variable for both models is the variation in the CPI (1\% of significance in both cases) that responds in reverse: with an increase in the price level, the arrears ratio decreases, most likely due to a lower incentive to credit and consumerism. 
Table 6. Summary table of estimated coefficients and robust standard deviation of estimates Fixed Effects vs. Random Effects

\begin{tabular}{|c|c|c|}
\hline Variable & Estimates Fixed Effects & Estimates Random Effects \\
\hline Morosityt-1 & $\begin{array}{c}0.98344 * * * \\
(.00634)\end{array}$ & $\begin{array}{c}0.95056 * * * \\
(.00791)\end{array}$ \\
\hline Net profit & $\begin{array}{c}-0.00005 * * \\
(.00002)\end{array}$ & $\begin{array}{c}-0.00004 * * * \\
(.00001)\end{array}$ \\
\hline Credit growht ratio & $\begin{array}{c}0.04527 * * \\
(.02237)\end{array}$ & $\begin{array}{l}0.04831 * \\
(.02293)\end{array}$ \\
\hline GDP vairiation & $\begin{array}{c}-0.02336 * * * \\
(.00327)\end{array}$ & $\begin{array}{c}-0.02379 * * * \\
(.00318)\end{array}$ \\
\hline Active interest ratio & $\begin{array}{c}0.0069 \\
(.00423)\end{array}$ & $\begin{array}{l}0.01012 \\
(.00602)\end{array}$ \\
\hline Unemployment ratio & $\begin{array}{l}-0.02315 \\
(.01701)\end{array}$ & $\begin{array}{c}-0.04083 * * \\
(.01545)\end{array}$ \\
\hline IPC variation & $\begin{array}{c}-0.06744 * * * \\
(.01358)\end{array}$ & $\begin{array}{c}-0.07579 * * * \\
(.01472)\end{array}$ \\
\hline Liquidity ratio & $\begin{array}{l}0.00164 \\
(.00148)\end{array}$ & $\begin{array}{l}0.00015 \\
(.00275)\end{array}$ \\
\hline CMAC & $\begin{array}{c}-0.00154 * * * \\
(.00056)\end{array}$ & (omitida) \\
\hline CRAC & $\begin{array}{c}-0.00333 * * * \\
(.00071)\end{array}$ & (omitida) \\
\hline EDPYME & (omitida) & (omitida) \\
\hline Constant & $\begin{array}{c}0.00402 * * \\
(.00182)\end{array}$ & $\begin{array}{c}0.00544 * * \\
(.00207)\end{array}$ \\
\hline
\end{tabular}

$* * * \overline{\mathrm{p}<0.01} * * \mathrm{p}<0.05 * \mathrm{p}<0.1$

The variables that are not significant are liquidity ratio or the active interest ratio.

e) Join significance (Test F)

In Table 7, it is confirme that both tests have a strong fit and reject the hypothesis that all $\beta$ together are equal to zero.

Table 7. Comparison of tests of joint significance

\begin{tabular}{lrr}
\hline Test Wald / F & Estimation random effects & \multicolumn{1}{c}{ Estimations fixed effects } \\
\hline Value & 452459.07 & 3470.26 \\
Prob $>$ F $\quad$ /chi2 & 0.000 & 0.000 \\
\hline
\end{tabular}

f) Best estimate panel to use

In order to classify the best model for the dynamic panel, the criteria to used will have three edges: Joint significance, Level of correction for heterogeneity not observed of constant effects over time and Hausman test - non-systematic difference between coefficients

In the first point both models are at a close level, however, to correctly analyze who has the best fit, the square root of the Wald statistic (random effects) must be compared vs the F statistic (fixed effects).

The square root of the Wald statistic yields a value of 452459.07 , while the F statistic has a value of 3470.26 , with which we can infer that the fixed effects model has a better fit.

Finally, we proceed to confirm what was analyzed through the Hausman Test, which analyzes the non-systematic 
difference between coefficients, thus determining:

$H_{0}=$ Consistent and inefficient fixed estimator < Estimate E. Consistent and efficient random

$H_{1}=$ Consistent E-fixed estimator $>>$ Inconsistent E. Random estimator

The test is base on a systematic difference of coefficients expressed under:

Hausman: $\left[\hat{\beta}^{F E}-\hat{\beta}^{R E}\right]^{g}\left[\operatorname{Var}\left(\hat{\beta}^{F E}\right)-\operatorname{Var}\left(\hat{\beta}^{R E}\right)\right]^{-1}\left[\hat{\beta}^{F E}-\hat{\beta}^{R E}\right]$

And the results in the present investigation are the following:

Table 8. Test de Hausman / comparative non-systematic difference

\begin{tabular}{cc}
\hline Test & Hausman \\
\hline Chi 2 & 30.54 \\
P. value & 0.000 \\
\hline
\end{tabular}

In addition, as you can see, the test rejects the null hypothesis; therefore the estimator of random effects, as already observed, would be inconsistent, while the fixed effects estimator would be the one to be use in dynamic panel modeling.

Finally, with this analysis, we determined that the final dynamic panel model should is base on the significant variables of the model, with an estimate of fixed effects, which should be contrasted with the Arellano Bond model.

\section{Results}

\subsection{Arellano Bond Estimator}

$$
\begin{aligned}
& \Delta \text { Morosid }_{i t}=\rho * \Delta \text { Morosid }_{i, t-1}+\beta_{1} * \operatorname{VarIPC}_{t}+\beta_{2} * \operatorname{VarPBI}_{t}+\beta_{3} * \mathrm{TCC}_{i t}+\beta_{4} * \\
& U N_{i, t}+\Delta v_{i t}
\end{aligned}
$$

Where:

$$
\operatorname{MMorosid}_{i_{2} t-1}=\rho *(\rho-1) \text { Morosid }_{i_{2} t-3}+(\rho-1) v_{i t-2}+v_{i t-1}
$$

In order to verify the relevance of the Arellano bond model, two tests were evaluate: the sargan verification test, and the Arellano Bond error differential correlation test.

a) Test de Sargan

Table 9. Test of valid identification of Sargan

\begin{tabular}{cc}
\hline Test & Sargan \\
\hline Chi2 & 216.6129 \\
P. value & 0.000 \\
\hline
\end{tabular}

Although the test shows that the null hypothesis that the model has a valid overidentification is rejecte, the value of chi2 is not so high as to consider the Arellano bond model as harmful, so the analysis is carry out.

b) Test de Arellano Bond

This test allows verifying that there is no autocorrelation between the differential of the errors, outside the order 1

(which if it must have because obviously $\operatorname{corr}\left(\Delta e_{i_{i}, t}, \Delta e_{i_{i} t-1}\right) \neq 0 \operatorname{corr}\left(\Delta e_{i_{s}, t}, \Delta e_{i_{s} t-1}\right) \neq 0$.Therefore, the 
structure of the error differential should be:

$$
\begin{aligned}
& \text { Order 1: } \operatorname{corr}\left(\Delta e_{i_{2}, t}, \Delta e_{i_{i} t-1}\right) \neq 0 \\
& \text { Order 2: } \operatorname{corr}\left(\Delta e_{i_{i}, t}, \Delta e_{i_{s} t-2}\right)=0 \\
& \text { Order 3: } \operatorname{corr}\left(\Delta e_{i_{i} t}, \Delta e_{i_{s} t-1}\right)=0 \\
& \text { Order n: } \operatorname{corr}\left(\Delta e_{i_{s},}, \Delta e_{i_{s} t-n}\right)=0 \quad\left({ }^{\prime} \mathrm{n}>1\right)
\end{aligned}
$$

Performing the respective test to the Arellano bond model, the following results are obtain:

Table 10. Non-autocorrelation error difference test - Arellano Bond

\begin{tabular}{lccc}
\hline \multicolumn{3}{c}{ Arellano Bond } \\
\hline Orden & & Valor Z & Prob> Z \\
& 1 & -3.2469 & 0.0012 \\
& 2 & 0.000 & 0.698 \\
\hline
\end{tabular}

A normal behavior of the error difference is visualized, with autocorrelation only of order 1 . This reaffirms the relevance of considering the Arellano bond model in the final analysis. Having completed the diagnosis of the Arellano bond model, the results are publishe.

\subsection{Dynamic panel Fixed Effects vs Arellano Bond Model}

The model:

$$
\begin{gathered}
\text { Morosid }_{i, t}=\gamma+\rho * \text { Morosid }_{i, t-1}+\beta_{1} * \operatorname{VarIPC}_{t}+\beta_{2} * \operatorname{VarPBI}_{t}+\beta_{3} * \mathrm{TCC}_{i, t}+\beta_{4} \\
* U N_{i, t}+v_{i, t}
\end{gathered}
$$

Using estimates fixed effects: $y_{i, t}-\bar{y}_{i}=f\left(X_{i t}-\bar{X}_{i}\right)$

Table 11. Summary of estimated coefficients and robust standard deviation (cluster id) of E. Fixed vs. E. Arellano Bond estimates

\begin{tabular}{lcc}
\hline \multicolumn{1}{c}{ Variable } & Estimación E. Fixed & Estimación A. Bond \\
\hline Morosity ratio & $0.94187 * * *$ & $0.85179 * * *$ \\
& $(.01196)$ & $(.04617)$ \\
Credit Growth ratio $(\mathrm{MN})$ & $-0.01983 * * *$ & $-0.01738 * * *$ \\
& $(.003)$ & $(.00334)$ \\
GDP variation & $-0.00005 * * *$ & $-0.00010 * * *$ \\
& $(.000001)$ & $(.000004)$ \\
Active interest ratio (to small companies) $(\mathrm{MN})$ & $0.04102 * *$ & $0.10501 * * *$ \\
& $(.01756)$ & $(.03058)$ \\
Unemployment ratio & $-0.05898 * * *$ & $\left(.05522^{* *}\right.$ \\
Constante & $(.01686)$ & $(.02639)$ \\
$* * * \mathrm{p}<0.01 \quad * * \mathrm{p}<0.05 * \mathrm{p}<0.1$ & $0.00571 * * *$ & $011985 * * *$ \\
\hline
\end{tabular}


As can be seen in Table 11, all the variables of the resulting models are significant at 5\% significance or more. However, Test F of the Dynamic Panel Model is vastly greater than the Wald test of the Arellano bond Model (1354.19 vs. 488.28$)$.

Taking into account the results, the most efficient model to analyze the behavior of the arrears index of client portfolio of the entities under study is a dynamic panel model of fixed effects with correction of cluster ID errors. The main reason for choosing is that it corrects the heterogeneities not observed due to the constant effects over time. On the other hand, Nickel's bias does not significantly affect the model, since it is of a considerable temporal nature (long panel), and the results obtained are superior to those analyzed by the Arellano-Bond estimate.

\section{Discussion}

The result of study indicates that the arrears ratio depends mostly on its lag from the previous period (with an effect of $94.2 \%$ ). These results coincide with the research by Quiñonez (2005), who conducted an investigation on the macroeconomic and microeconomic determinants of arrears loans granted by Ecuador's private banking system. The investigation showed that from the first quarter of 1995 until the first quarter of 2005, the lagged values of arrears contribute to explain the contemporary level of this indicator.

Also the model demonstrates a positive reaction of the arrears ratio to the credit growth rate (Effect of $4.1 \%$ ), which implies that while the level of credit continues to increase, the arrears rate will increase, and this has a key impact on the inclusion of people who are not always subject to credit, an increasingly common practice in the sector.

The arrears ratio also reacts negatively to the variation in GDP (with a $2 \%$ coefficient), which means that the arrears ratio decreases in times of economic boom. These results also coincide with (Diaz, 2009), who determined that there is an inverse relationship between the GDP growth rate and the arrears ratio. Additionally, Vallcorba \& Delgado (2007), they also consider that there is a negative relationship between GDP, arrears, since in times of economic prosperity families generate higher incomes and therefore their ability to pay is improved, and the level of arrears decreases. Likewise, the results of their models suggest a negative relation to the variables related to the liquidity and level of indebtedness of people.

Similarly, the arrears ratio also reacts negatively to the variation in the CPI (Effect of 6\% on the dependent variable), which means that the arrears ratio decreases due to a lower level of consumption and / or change to the conservative profile, by consumers, given a scenario of rising prices. According to author such as Chavarín (2015), Climent \& Pavia (2014) and Dietrich \& Wanzenrieg (2011) another of the variables that usually include the authors who carry out this type of research, is inflation, while it is mention that this measures the level of prices that the population faces and is decisive to harm or benefit the situation of its debt. Also Altuve \& Hurtado (2018) considered the real passive interest rate as variable in which they manage to find a positive relationship with the arrears.

The variable with the lowest effect on the arrears ratio is net income, being practically imperceptible; however, it leaves a very interesting analysis. There is a minor relationship between how much better the microfinance entity is doing and the arrears rate, and this may be due to the options for reselling arrears portfolios, or debt restructuring, which are already implement in the sector.

Given this empirical evidence, it is expect that the results obtained are use both by the microfinance entities themselves and by the regulatory entity in order to generate an enabling environment to reduce the arrears in payment.

\section{Conclusions}

The present study is relevant because it allows identifying the factors that influence the arrears of microfinance entities, which could have repercussions on the development of these institutions by promoting a more solid and sustainable system in the short and long term, which improves the financing of Mype sector of Peru.

For this purpose, we used an econometric stimation a dynamic panel data model with fixed effects was use, because it corrects heterogeneities not observed by constant effects over time, and has the dynamic character necessary for the arrears ratio. The empirical model estimated was consistent, because achieved a satisfactory explanation of the determinants of arrears in Peru, through the econometric model it is evident that Nickel's bias doesn't significantly impact the model as it is of a considerable temporal nature (long panel), and the results obtained are superior to those analyzed by the Arellano-Bond estimate.

Likewise, it was find that the credit growth rate, the variation of the GDP and the CPI, in addition to the net profit are variable variables for the model. This specific situation is in line with the evidence found in the literature. Thus, it was find that past arrears levels directly influence current arrears. From the results detected, it is observe that the 
arrears is affected by multiple variables, micro and macro economic level. In addition, these variables are directly relate to the level of wealth of the population, expectations generated by the economic policy, and in turn with the relative evolution of microfinance institutions, which show an increase in their credit levels, in the search for higher profits. However, the previous lag of the same variable is a fundamental determinant for the analysis, implying the relevance of the temporal analysis in the panel used.

From some limitations found by the study, lines of research are opened, one of them is the possibility of estimating other economic models of medium or high complexity, such as autoregressive vectors in which it also considers short and long-term adjustments in the parameters. Another of them is through the ARIMA model that focuses predict future points in the series.

Finally, based on the estimated model, it can be used to make estimates and predictions of the arrears ratio. In this sense, this instrument is vital and important for regulatory entities that are in charge of controlling the Peruvian financial system, as warning signs, and recommend that microfinance entities implement action plans when arrears levels are not in accordance with the tolerance handled by each entity since this could successively affect the arrears ratios recorded. In addition, it helps to contribute to better functioning and supervision, as well as to prevent financial instability and counteract financial imbalances for a more stable economy.

\section{References}

Aguilar, G., \& Camargo, G. (2003). Análisis de la morosidad de las instituciones microfinancieras en el Perú. Lima: CIES.

Altuve, J., \& Hurtado, A. J. (2018). Análisis de los factores que influyen en la morosidad del sistema bancarios venezolano (2005 - 2015). Revista Venezolana Análisis de Coyuntura, 24(1).

ASBANC. (2016). Análisis del comportamiento de la morosidad. ASBANC Semanal, 1-5.

Banco Central de Reserva del Perú. (2018). Reporte de Estabilidad Financiera. Lima: BCRP.

Bernanke, B., \& Gertler, M. (1989). Agency Costs, Net Worth, and Business Fluctuations. American Economics Review, 79(1), 14-31.

Caprio, G. (1998). Banking on Crises: Expensive Lessons from Recent Financial Crises. Development Research Group, 30-40.

Caprio, G., \& Klingebiel, D. (1996). Bank Insolvencies: Cross-Country Experience. World Bank Working Papers, 60-76.

Chavarín, R. (2015). Morosidad en el pago de créditos y rentabilidad de la banca comercial en México. Revista Mexicana de Economía y Finanzas- Nueva Época, 71-86.

Climent, S., \& Pavia, J. (2014). Determinantes y diferencias en la rentabilidad de cajas y bancos. Revista de economía aplicada, 117-154.

Diaz, O. (2010). Determinantes del ratio de morosidad en el sistema financiero boliviano. La Paz: Banco Central de Bolivia.

Dietrich, A., \& Wanzenrieg, G. (2011). Determinants of bank profitability before and during the crisis: Evidence from Switzerland. Journal of International Financial Markets, Institutions \& Money, 307-327.

Ergungor, O., \& Thomson, J. (2006). Systemic Banking Crises. Research in Finance, 23, 279-310.

Gonzalo, L., \& Panizza, U. (2015). La gran depresión de la economía peruana: ¿Una tormenta perfecta?. Revista Estudios Económicos, (30), 91-217.

Guillén, J. (2001). Morosidad crediticia y tamaño: Un análisis de la crisis bancaria peruana. Revista de concuso de Ivestigación para Jóvenes Economistas.

Gutierrez, J. (2008). Microfinanzas y desaroollo: situación actual, debates y perspectivas.

Hardy, D., \& Pazarbasioglu, C. (1999). Determinants and leading indicators of banking crises: further evidence. IMF Staff Paper, 46(3), 247-258.

Hermes, N. (2014). Does microfinance affect income inequality?. Applied Economics, 46(9), 1021-1034.

Lender, K. (2019). Microfinance Info. Obtenido de https://microfinanceinfo.com/history-of-microfinance/

Levin, A., Lin, C. F., \& Chu, C. S. (2002). Unit root test in panel dataa: asymptotic and finite-sample properties. Journal of Econometrics, 108, 1-24. 
McCann, F., \& MacIndoe Calder, T. (2012). Bank competition through the credit cycle: implications for MSE Financing. Conferencia presentada en the Central Bank of Ireland conference. The Irish SME Lending Market: Descriptions, Analysis, Prescriptions, 2 de marzo de 2012. Retrieved from http://sme.ebi.gov.eg/Documents/Finance/Bank\%20competition\%20through\%20the\%20credit\%20cycle\%20im plications \%20for\%20SME\%20financing.pdf

Microfinanzas Global. (2019). Microfinanzas. Retrieved from https://microfinanzasglobal.com/definicion/peru/

Ministerio de Producción. (2018). Estadística MIPYME.

Morón, E., \& Rudy, L. (2003). Sistema de Alerta Temprana de Fragilidad Financiera. Universidad del Pacifico, 7-14.

Muñoz, J. (1999). Calidad de cartera del sistema bancario. Estudios Económicos - Banco Central de Reserva del Perú, 107-118.

Murrugarra, E., \& Ebentreich, A. (1999). Determinantes de morosidad en entidades de microfinanzas: evidencia de las Edpymes.

Quiñonez, R. (2005). Determinantes de la Morosidad en el Sistema Bancario del Ecuador 1995-2005. Quito.

Quispe, Z., León, D., \& Contreras, A. (2012). El exitoso desarrollo de las microfinanzas en el Perú. Revista Moneda, 13-18.

Robinson, M. (2001). The microfinance revolution. Washington, D.C.: New York: World Bank Open Society Institute.

Seibel, H. D. (2003). History matters in microfinance. Small Enterprise Development - An International Journal of Microfinance and Business Development, 10-12.

Superintendencia de Banca, \& Seguros y AFP. (2019). Superintendencia de Banca, Seguros y AFP. Retrieved from http://www.sbs.gob.pe/supervisados-y-registros/empresas-supervisadas/directorio-del-sistema-financiero/edpym es-empresas-de-desarrollo-de-pequena-y-microemp

Tzavallis, E., \& Harris, R. (1999). Inference for unit roots in dynamic panels where the time dimension is fixed. Journal of Econometrics, 201-226.

Vallcorba, M., \& Delgado, J. (2007). Determinantes de la morosidad bancaria en una economía dolarizada. el caso uruguayo. Madrid: Banco de España.

\section{Notes}

Note 1. It must meet some rules or norms propused by the SBS

Note 2. Fernacrep is responsible for monitoring or directing the performance of the institution's own activities.

Note 3. Las cooperativas de ahorro y crédito no autorizadas a captar recursos del público (Coopac) constituyen uno de los vehículos de cooperación social más antiguos del Perú, y su importancia para el desarrollo económico y la inclusión financiera del país es innegable, especialmente en aquellos sectores más lejanos y vulnerables del Perú. Savings and credit cooperatives not authorized to capture resources from the public (Coopac) constitute one of the oldest vehicles for social cooperation in Peru, and their importance for the economic development and financial inclusion of the country is undeniable, especially in those sectors distant and vulnerable of Peru. SBS, under Law No. 30822 (which entered into force on January 1, 2019), has been commissioned to supervise these entities, for which it has worked laying the foundations of a new regulatory framework that respects the nature and cooperative principles, and implementing the actions to accompany the Coopac in this process.

Note 4. 166 entities supervised by the SBS.

Note 5. File Múltiple SBS N 10250-2017 